\title{
An Electron Microscopic Study of the Ultimobranchial Body of the Crucian Carp (CARASSIUS CARASSIUS)
}

\author{
By \\ Isamu Takagi and Keiki Yamada \\ Department of Anatomy, Fujita-Gakuen University School \\ of Medical Technology and Nursing, Toyoake City, \\ Aichi Prefecture 470-11, Japan \\ -Received for Publication, March 26, 1977-
}

The parafollicular cells which exist in the thyroid gland of the mammals were located by Baber (1876) and Nonidez (1932a, b; 1933). It has since been reported that these parafollicular cells are derived from the ultimobranchial body and dissolve into the thyroid gland (Godwin, 1937 ; Tashiro, 1963,1964 ; Ishikawa, 1965; Sato et al., 1966 ; Sugiyama, 1969, 1971 ; Sugiyama et al., 1969). The parafollicular cells are also said to secrete calcitonin which possesses a hypocalcemic function antagonizing the function of parathyroid hormone (Copp et al., 1961, 1962 ; Hirsch et al., 1963, 1964). Pearse and others (Pearse, 1966 ; Pearse et al., 1967) in the meantime, succeeded in observing the secretion of calcitonin from parafollicular cells by means of an immunofluorescence technique.

In the birds and the amphibians thyroid glands and ultimobranchial bodies are found separately (Watzka, 1933; Dudley, 1942; Saxen et al., 1955; Nagy et al., 1966). Thus, it has often been questioned that the ultimobranchial bodies of these animals might also be related to the calcium metabolism (Watzka, 1933 ; Sehe, 1960 ; Copp, et al., 1967, 1969 ; Malmquist et al., 1968; Clark, 1968).

Some electron microscopic studies of the ultimobranchial body of the fishes have been reported by Robertson (1969 in the rainbow trout) and by Kitoh (1970 in the Elasmobranchs). The present authors have conducted a similar study of the crucian carp (CARASSIUS CARASSIUS), one of teleostei, under an electron microscope from a standpoint of comparative anatomy.

\section{Materials and Methods}

Crucian carps for this study were collected in several ponds in Toyoake area, Aichi Prefecture, during the months from March to 
August. The total of nineteen crucian carps had varying body lengths of 12 to $22 \mathrm{~cm}$ and body weights of 25 to $180 \mathrm{~g}$.

The ultimobranchial body of each fish was extracted according to Sehe's reported (1960) by cutting out the exterior region of the ventral aspect of the esophagus at the level of the sinus venosus close to the pharyngeal teeth.

The extracted samples were first prefixed in $2 \%$ glutaraldehyde -2.5\% paraformaldehyde buffered with phosphate ( $\mathrm{pH} 7.4$ ) for 1 hour at $4^{\circ} \mathrm{C}$. Then they were cleansed overnight in $0.2 \mathrm{M}$ phosphate buffer containing saccharose. Finally, they were fixed for 1 hour in $2 \%$ osmic acid buffered with Millonig's phosphate buffer ( $\mathrm{pH}$ 7.4) with a glucose additive. Later, they were dehydrated with ethanol, replaced by n-BGE, and embedded in Epon 812 resin according to Luft's method (1961).

Sample sections were cut out on Porter-Blum MT-II and LKB 8800 ultramicrotomes. Thick section $(1 \mu)$ for light microscopy were stained according to Sato's method (Sato et al., 1973), and the initial observation of the ultimobranchial bodies were made. Then, after having trimmed these sections, the ultimobranchial bodies were further observed by means of Shamoto's method (Shamoto et al., 1974) of a simultaneous observation of the identical object by light and electron microscopes. Thin sections, on the other hand, were stained twice by uranyl acetate (Watson, 1958) and lead (Sato, 1968) and were observed under a HITACHI HU $12 \mathrm{~A}$ electron microscope.

\section{Observations}

The ultimobranchial body of the crucian carp was located in the vicinity of the exterior region of the esophagus ventralis and could be found as a cluster of cells gathered on the outside of the circular musculature (striated muscle) of the esophagus. The ultimobranchial body formed a lobule which was enclosed by fibrillar connective tissues containing a number of blood capillaries. Inside the lobule were a group of cord-like arrangements.

The follicle consisted of a single layer of cubical or columnar epithelial cells. The nuclei were generally arranged along the basal border. Each follicle measured between 30 and $55 \mu$. A number of microvilli were found projected into the follicular lumen. Inside the follicular lumen were various pleomorphic substances including some cell detritus (Figs. 1, 2, 3).

There were three kinds of cells forming each follicle : light cells, semi-dark cells, and dark cells (Figs. 1, 2, 3).

In the light cells, both cytoplasm and nucleus had circular to elliptical shapes in most of the cases. But, occasionally, the apical cytoplasm was pointed toward the follicular lumen. The nucleus normally occupied 
$1 / 3$ to $1 / 2$ of the cytoplasm. The cytoplasm had a heterogeneous appearance with thin and short rough-surfaced endoplasmic reticulum and granules of varying shades $(0.2$ to $0.3 \mu)$ possessing membrane-bound scattered about. As for the Golgi apparatus, a process resembling a granules production was observed. Vary rarely, fibrous filament bundles were found (Figs. 4, 5).

The dark cells were found penetrating into the gaps between the light cells and enclosing the follicular lumen. Cytoplasm and nuclei of the dark cells were polygonally shaped and the nucleus occupied most of the cytoplasm. Some cells had cytoplasmic granules of 0.5 to $1.0 \mu$ in diameter. A number of free ribosomes were scattered in the cytoplasm. There were a small number of mitochondria and rough-surfaced endoplasmic reticulum adjacent to the follicular lumen. It was also possible to observe some pleomorphic microvilli projected into the follicular lumen possibly indicating the cellular debris in that area (Figs. 1, $2,3,4)$.

At the apical border of the dark cells which extended from the basal border and met with each other there, cellular interdigitations were prominent and well-developed desmosomes and Golgi apparatus were clearly observed (Fig. 6). It was also possible to observe in this area a number of figures which might possibly be parts of the light cells sliced near their tangential lines (Figs. 5, 6).

Although the light cells were normally bounded by the dark cells, occasionally, some light cells were found connected with each other by penetrating through the dark cells (Fig. 3). Furthermore, some light cells discharging some of its substances into the follicular lumen by penetrating through the dark cells were often observed (Figs. 7, 8, 9, 10).

The semi-dark cells showed many similarities to the light cells, though their cytoplasm appeared darker. This was caused by a more dense distribution of granules as compared with the light cells. Also prominent were some blank spots vesicles which looked as if some granules had been removed from there (Fig. 4). Just like the light cells, some semi-dark cells were also penetrating through the dark cells and projecting into the follicular lumen. The apical cytoplasm showed a trace of destruction in such cells (Fig. 11).

Cells projecting into the follicular lumen were found among any of light cells, semi-dark cells, or dark cells. But no cells were found among the dark cells whose cytoplasm itself was projecting into the lumen along with microvilli. Rather, it appeared as if the dark cells were ejecting some substance produced therein or absorbing some substance from the follicular lumen (Figs. 12, 13, 14).

Substances existing completely independently within the follicular lumen had various shapes (Figs. 7, 8, 9).

Adjacent to the basal borders of some follicles, cells different from 
those described above were observed (Figs. 15, 16, 17, 18). These cells had a number of granules of very high electron density and a large and clear nucleolus also of high electron density. Cytoplasma of some cells of this type appeared extremely light and of the others rather dark. The darker cells of this kind had very well-developed roughsurfaced endoplasmic reticulum and many large and long mitochondria (Figs. 16,17). The numerous cytoplasmic granules of varying electron density measuring approximately 0.2 to $0.4 \mu$ in diameter possessed membrane-bound. These granules were very similar to secretory granules of parafollicular cells.

Very rarely, radiating fibers resembling an osmiophilic structure were observed (Fig. 19).

\section{Discussion}

The ultimobranchial body of the crucian carp mostly consists of several follicles, cords-like cells, and blood capillaries. There are three types of cells constituting the follicle: light cells, semi-dark cells, and dark cells. All of these contain some cytoplasmic granules. In addition to these, another type of cells, granule-rich cells containing a number of various granules, were observed adjacent to the basal border of the follicle.

It has already been reported that parafollicular cells of the mammals secrete calcitonin which possesses a hypocalcaemic function (Copp, 1961, 1962 ; Hirsch et al., 1963, 1964 ; Pearse, 1966 ; Pearse et al., 1967).

Many studies are being undertaken on the assumption that these parafollicular cells develop from the ultimobranchial body in embryo. The first electron microscopic observation of the ultimobranchial bodies and parafollicular cells was made by Tashiro $(1963,1964)$. He clarified the relationship of the two by demonstrating that mitochondria and rough-surfaced endoplasmic reticulum had common features in the parafollicular cells of dog's thyroid gland and the follicular cells of the ultimobranchial body. A number of other studies have been conducted to probe this point in man (Grosser, 1910), in moles and guinea pigs (Rable, 1913), in pigs (Badertscher, 1918), in rats (Rogers, 1927), in rabbits (Togari et al., 1951), in dogs (Tashiro, 1963), in rats (Ishikawa, 1965), in guinea pigs (Machida et al., 1962), in hamsters (Sato, 1959), in mice (Sato et al., 1966), in rats (Sugiyama, 1940), in mice (Sugiyama, 1942), in guinea pigs (Sugiyama, 1954), in man (Sugiyama, 1969, 1971), in man (Sugiyama et al., 1969), and in hamsters (Takagi et al., 1974).

Summarizing the above studies, it can be concluded that the ultimobranchial body is dissolved in the thyroid gland in embryo and develops into parafollicular cells.

In the lower vertebrates the ultimobranchial body and thyroid gland 
exist as independent organs. Copp and others $(1967,1969)$ report that the ultimobranchial extractives from the chicken and the shark showed a hypocalcaemic function after injecting them into rats. There have been a number of studies concerning the secretion of calcitonin in lower vertebrates (Watzka, 1933 ; MacIntyer, 1967 ; Sehe, 1960 ; Tauber, 1967 ; Moseley, 1968 ; Clark, 1968; Malmquist et al., 1968 ; Hurst et al., 1969 ; Dent, 1969).

Electron microscopic studies of ultimobranchial bodies have been conducted in guinea pig (Rable, 1913), in man (Grosser, 1910 ; Kingsbury, 1915), in dogs (Godwin, 1937) as studies in the mammals. They report that the ultimobranchial body possesses epithelial cysts of cubical or columnar structures and some other clusters of cells of polygonal structures. Furthermore, similar studies have been conducted by Sugiyama in mice (1942), by Swartz in hamsters (1964), and by Takagi and others in hamsters (1974).

As for the amphibians, Greil (1905) and Maurer (1906) report the ultimobranchial body possesses follicles and forms cellular complexes.

In the reptiles, Eggert (1938a, b) reports the ultimobranchial body has follicles containing colloidal substances in which cells with very little cytoplasm are arranged in a number of pseudo-stratified epithelium. Chromatophres and blood capillaries are also reported.

In the birds, Dudley (1942) and Sehe (1965) report the ultimobranchial body can be found in the vicinity of the glomus carotium.

In the fishes, Watzka $(1933)$ and Sehe $(1960,1965)$ report the ultimobranchial body possesses some large follicles containing colloid, pigment cells, and a number of blood capillaries.

As for the teleostei, after studying carp, goldfish, and catfish, Sehe (1960) reports as follows: The ultimobranchial body of the carp can be found on the exterior region of the ventral aspects of the esophagus at the level of the sinus venosus. Here, a cluster of follicles containing an abundance of connective tissues can be found. Within the follicles, there are many granules and degenerate nuclei. In the goldfish, the ultimobranchial body does not have as many follicles as that of the carp. In the catfish, one can observe only a trace of ultimobranchial body. The report by Lopez and others (1968) also agree with the above report concerning the catfish. Oguri (1973), after studying goldfish, reports the ultimobranchial body forms a lobule containing follicles and funicular cells. Some nerve cells and large spaces for blood capillaries can also be found.

After conducting a light microscopic study of the ultimobranchial body of the crucian carp, the present authors have obtained the similar result to those reported by Sehe (1960) and Oguri (1973) in many respects such as the location of the ultimobranchial body, the connective tissues in its vicinity, the existence of the follicles, and the cord-like arrange- 
ment of the cells.

Steinitz and others (1954) and Stoeckel and others (1969) both report that two kinds of cells were found in the ultimobranchial body of the newt and the chicken respectively. Robertson (1965) reports six types of cells, the development of ergastoplasm, some secretory granules, and goblet cells in the ultimobranchial body of the frog. Robertson (1967) has also observed the projection of cellular and nuclear debris in the ultimobranchial follicles of the frog.

As for karyodierese, Watzka (1933) and Schaefer (1938) report the observation of the occurrence, but Kitoh (1970) does not.

There have been many studies of the ultimobranchial body of the lower vertebrates such as in tortoise (Muramoto, 1962), in frog (Robertson, 1965), in frog (Robertson et al., 1965), in chicken and hamsters (Stoeckel et al., 1967a, b), and in chicken (Stoeckel et al., 1969). Muramoto (1962) reports that the ultimobranchial body of most lower vertebrates has irregularly shaped nuclei, circular or elliptical mitochondria, a fow poorly-developed rough-surfaced endoplasmic reticulum, and a few granules.

Electron microscopic studies of the ultimobranchial body of the fish have produced two conflicting results: On the one hand, Robertson (1967, 1969 in goldfish and rainbow trout), Lopez and others (1968 in eel), and Kitoh (1970 in stingray and goldfish) report the ultimobranchial body forms follicular structures; on the other hand, Pang (1971 in killifish), and Copp (1969 in rainbow trout) report it forms funicular structures.

However, Eggert (1938a, b in fishes) and Rasquin and others (1954 in teleostei) argue that follicular structure and the funicular structure are two interchanging states resulting from the condition of the ultimobranchial body either being normal or hypertrophic.

According to Steinintz and others (1954 in newt), Copp (1969 in sharks) and Stoeckel and others (1969 in chicken), the ultimobranchial cells can be classified into two types: one type possessing an abundance of mitochondria and granules, the other type possessing a light nucleus and a few mitochondria and granules. Kitoh (1970) in his study of the stingray and the dogfish, classifies the cells into two kinds: barrel cells and finger cells. The barrel cells are endocrine in their nature containing a number of secretory granules. The granules are assumed to have been produced in the Golgi apparatus. Filament bundles are formed around the nuclei. The finger cells enclosing the barrel cells are those possessing the characteristics of the epithelium of the pharyngeal pouch which can be seen in the early stage of the development. They also form microvilli at the apical border.

Robertson (1965 in frog and 1969 in rainbow trout), and Robertson and others (1965 in frog) also report the observation of secretory granules, 
the development of the Golgi apparatus, and its process of granular production. He also mentions the osmiophilic granules.

The electron microscopic observation of the ultimobranchial body of the crucian carp undertaken by the present authors can be compared with the reports of the others as follows:

The nuclei in the crucian carp are generally located on the basal border, and this fact agrees with Robertson's report (1969) on the rainbow trout. But the cells do not have a tall columnar shape as Robertson (1969) reports.

The crucian carp possesses follicles. Here, the authors were unable to observe any colloidal substances as reported by van Bemmeln (1886 $\mathrm{a}, \mathrm{b}$ in the elasmobranchs) or glycogen as reported by Machida and others (1962 in guinea pigs). But cellular debris were observed as reported by Camp (1917), Watzka (1933) and Sehe (1960).

As for the types of cells in the crucian carp, similarities were found with Kitoh's report (1970) on the elasmobranchs in the following points: (1) The light cells and the dark cells of the crucian carp show similarities to the barrel cells and the finger cells of the elasmobranchs respectively. The semi-dark cells are similar to the barrel cells. (2) Granules which might have been produced in the Golgi apparatus can be seen, and they are scattered in the cytoplasm. (3) Filament bundles can be seen in the cytoplasm.

The existence of microvilli on the apical border and the projection of cellular substances into the follicular lumen agree with reports by Copp (1969 in sharks), Robertson (1969 in fishes), and Kitoh (1970 in elasmobranchs).

Although Watzka (1933 in fishes), Schaefer (1938 in newts), and Robertson (1969 in fishes) report the observation of karyomitosis at the apical border, the present authors were not able to observe it in the crucian carp just as Kitoh (1970) was not in the elasmobranchs.

Osmiophilic radiating fibers have been observed just as in Robertson's (1969) and Stoeckel and others' (1967a, in chicken) observations.

As seen above, the ultimobranchial structure of the crucian carp shows a number of similarities to that of the carp and the chondrostei reported by Sehe (1960), Camp (1917), Copp (1969), and Kitoh (1970). But it somewhat differs from that of the rainbow trout, eel, and goldfish reported by Robertson (1969), Lopez and others (1968), and Oguri (1973). Therefore, the structures of the ultimobranchial body cannot necessarily be determined by the existing systematic classification of the fishes.

Kent (1969 in vertebrates) and Lagler and others (1962 in fishes) state the ultimobranchial body possesses the same function as the parathyroid gland. Pang (1971 in fishes) considers that it is related to the calcium metabolism and has a close relationship with the pituitary body ; furthermore, he points out the necessity to take the function of 
the corpuscles of Stannius into consideration.

Although the ultimobranchial body of crucian carp has granule-rich cells, no cells equivalent to these cells have been observed in other fishes. These cells have large nucleolus and well-developed mitochondria and rough-surfaced endoplasmic reticulum, and may possibly be producing some protein compound. They are very similar to parafollicular cells of the mammals. It has been reported by Matsuzawa (1969 in mice), Murakami (1970 in rats), and Kameda (1973 in dogs) that the parafollicular cells are filled with cytoplasmic granules of varying electron densities which might be granules containing secreted calcitonin. The present authors take a view that these granule-rich cells of the crucian carp perform the same function as parafollicular cells.

\section{Summary}

As a study in comparative anatomy an electron microscopic study of the ultimobranchial body of the crucian carp, one of teleostei, was conducted and the following results were obtained:

1. The ultimobranchial body of the crucian carp forms a lobule which has a follicular or cord-like arrangement and is enclosed by abundant fibrillar connective tissues and blood capillaries.

2. A follicle measures 30 to $55 \mu$ and a number of microvilli are projecting into the follicular lumen. Some cell detritus can be observed within the lumen.

3. A follicle generally consists of three kinds of cells : light cells, semi-dark cells, and dark cells.

4. Both cytoplasm and nucleus of the light cells have circular to elliptical shapes. Within the cytoplasm, which appears heterogeneous, thin rough-surfaced endoplasmic reticulum are scattered about and granules of 0.2 to $0.3 \mu$ of varying shades can be found. The Golgi apparatus often shows a figure indicating a possible production of the granules.

5. The dark cells penetrate deeply into the gaps between the light cells and also enclose the follicular lumen. The nucleus and cytoplasm of these dark cells are irregularly shaped and the nucleus occupies most of the cytoplasm. Occasionally, granules measuring 0.5 to $1.0 \mu$ can be found in the cytoplasm of the dark cells. Cellular interdigitations and desmosomes are commonly found at the apical border of the dark cells.

6. The semi-dark cells have a number of similarities to the light cells. But they possess more cytoplasmic granules than the light cells.

7. Some of the cells adjacent to the basal border-being different from the above-mentioned three kinds of cells-possess a large number of granules measuring 0.2 to $0.4 \mu$. A nucleolus is extremely distinct 
and rough-surfaced endoplasmic reticulum and mitochondria also have clear shapes. The cells show a great similarity to parafollicular cells of the mammals.

\section{Acknowledgements}

The authors express their gratitude to Assistant Professor Dr. Mikio Oguri, the University of Nagoya, for his valuable discussions and assistance throughout this study. We also wish to thank Mr. Taizan Sato, Joint Electron Microscopic Laboratory, for his skillful technical assistance.

\section{Literature cited}

1) Baber, E. C. : Contributions to the minute anatomy of the thyroid gland of the dog. Proc. Roy. Soc. 24 : 240-241, 1876.

2) Badertscher, J.A.: The fate of the ultimobranchial body in the pig (Sus scrofa). Amer. J. Anat. 23 : 89-131, 1918.

3) Camp, W.E.: The development of the suprapericardial (postbranchial, ultimobranchial) body in Squalus acanthias. J. Morph. 28 : 369-415, 1917.

4) Clark, N.B.: Calcitonin studies in turtles. Endocrinology. 83: 1145-1148, 1968.

5) Copp, D.H.: The ultimobranchial gland and calcium regulation. In: Fish Physiology. Vol. II. Hoar, W.S., and Randall, D. T, eds. Academic Press. N. Y. 377-398, 1969.

6) and Cameron, E. C.: Demonstration of a hypocalcemic factor (Calcitonin) in commercial parathyroid extract. Science. 134:2038, 1961.

7) —_ Cheney, B. A., Davidson, A, G. F., and Henze, K. G. : Evidence for calcitonin-A new hormon from the parathyroid that lowers blood calcium. Endocrinology. $70: 638,1962$.

8) - Cockeroft, D. W., and Kueh, Y.: Calcitonin from ultimobranchial gland of dogfish and chickens. Science. $158: 924-925,1967$.

9) Dent, P. B., Brown, D. M., and Good, R. A.: Ultimobranchial calcitonin in the developing chicken. Endocrinology. 85: 582-585, 1969.

10) Dudley, J.: The development of the ultimobranchial body of the Fowl, Gallus domesticus. Amer. J. Anat. $71: 65-97,1942$.

11) Eggert, B.: Der ultimobranchiale Körper. Endokrinologie. 20:1-7, 1938a.

12) : Der ultimobranchiale Körper der Knochenfische. Z. Zellforsch. 27 : 754763, $1938 \mathrm{~b}$.

13) Godwin, M.C. : Complex IV in the dog with special emphasis on the relation of the ultimobranchial body to interfollicular cells in the postnal thyroid gland. Amer. J. Anat. 60: 299-339, 1937.

14) Greil, A.: Ueber die Anlage der Lungen sowie der Ultimobranchialen (postbranchialen, supraperikardialen) Korper bei anuren Amphibien. Anat. Hefte. Arb. Anat. Inst. Wiesbaden. 29 : 455-506, 1905.

15) Grosser, O.: Zur Kenntnis des ultimobranchialen Körpers beim Menschen. Anat. Anz. $37: 337-342,1910$.

16) Hurst, J.G., and Newcomer, W.S.: Functional accessory parathroid tissue in ultimobranchial body of chick. (34258) 1969.

17) Hirsch, P.F., Gauthier, G.F., and Munson, P. L.: Thyroid hypocalcemic principle and recurrent laryngeal nerve injury as factors affecting the response to para- 
thyroidectomy in rats. Endocrinology. $73: 244-252,1963$.

18) - Voelkel, E.F., and Munson, P.L.: Thyrocalcitonin hypocalcemic hypophosphatemic principle of the thyroid gland. Science. 146:412-413, 1964.

19) Ishikawa, K.: Electron microscopical studies of the ultimobranchial body of the rat in embryonic life, with special emphasis on its fate. The relation to the thyroid tissue and parafollicular cells. Okajimas Fol. anat. jap. 41:313-335, 1965.

20) Kameda, Y.: Electron microscopic studies on the parafollicular cells and parafollicular cell complexes in the dog. Arch. histol. jap. 36(2): 89-105, 1973.

21) Kent, G.C.: Comparative anatomy of the vertebrates. Mosby Company. 406-412, 420-421, 1969.

22) Kingsbury, B.F.: On the so-called ultimobranchial body of the mammalian embryo: man. Anat. Anz. 47:609-627, 1915.

23) Kitoh, J.: Electron microscoic studies of the ultimobranchial body of the elasmobranchs. Arch. histol. jap. 31(3/4): 269-281, 1970.

24) Lagler, K., Bardach, J.E., and Miller, R.R.: The study of fishes., Ichthyology, John Wiley \& Sons, Inc., New York. London. 97-99, 352-353, 360, 1962.

25) Lopez, E., Deville, J., and Bagot, E. : Étude histophysiologique du corps ultimobranchial d'un téléostéen (Anguilla anguilla $L$ ) au cours d'hypercalcemia expérimentales. C. R. Acad. Sci. Paris, 267 10:1531-1534, 1968.

26) Luft, J. H. : Improvements in epoxy resin embedding methods. J. Biophys. Biochem. Cytol. 9 : 409-414, 1961.

27) Machida, Y., and Sugiyama, S.: The fate of the ultimobranchial body of the guinea pig and its relation to thyroid development. Okajimas Fol. anat. jap. 38: 73-87, 1962.

28) MacIntyre, I.: Calciltonin : A general review, Calcified Tissue Res. 1: 173-182, 1967.

29) Malmquist, E., Ericson, L.E., Malmquist, S., and Ekholm, R.: Granulated cells, uptake of amine precursors and calcium lowering activity in the ultimobranchial body of the domestic fowl. J. Uitrastr. Res. 23: 457-461, 1968.

30) Matsuzawa, T.: Experimental morphological studies on the parafollicular cell of the rat thyroid gland, with special reference to the source of thyrocalcitonin. Arch. histol. jap. 27 : 521-544, 1966.

31) - and Kurosumi, K.: Morphological changes in the parafollicular cells of the rat thyroid glands after administration of calcium shown by electron microscopy. Nature. 213: 927-928, 1967.

32) Maurer, F.: Die Entwicklung des Darmsystems. Hertwigs Handbuch der vergleichenden und experimentellen Entwicklungslehre der Wirbeltiere, Bd. 2, Teil, S. 109-252. Jena : G. Fischer 1906.

33) Michaelucci, S.: Richerche autoradiografiche sul corpo ultimobranchialen die cheloni (Testudo hermanni). Atti. Soc. Sc. Nat., Ser. B. 68 : 195-196, 1961.

34) Moseley, J. M., Matthews, E. W., Breed, R. H., Galante, L., Tse, A., and Macintyre, I.: The ultimobranchial origin of calcitonin. Lancet. 1:108-110, 1968.

35) Murakami, K.: Electron microscopic studies on the effect of long-term hypercalcemia on the thyroid parafollicular cell and the parathyroid cell of rats. Arch. histol. jap. 32: 155-178, 1970.

36) Muramoto, K.: Electron microscopic observations on the thyroid of Clemmys japonica. Acta. Anat. Nipp. $37: 63,1962$ (Abstract).

37) Nagy, F., and Swartz, G. F.: The ultimobranchial body of the chick embryo. Trans. Amer. Microsc. Soc. 85: 485-505, 1966.

38) Nanba, H., and Fujita, H.: Fine structure of the thyroid parafollicular cells in normal, vitamin $\mathrm{D}$ and $\mathrm{CaCl}_{2}$-treated, and $\mathrm{CaCl}_{2}$-treated mice. Arch. histol. jap. $30: 283-293,1969$. 
39) Nonidez, J.F.: The origin of the 'parafollicular' cell, a second epithelial component of the thyroid gland of the dog. Amer. J. Anat. 49: 479-505, 1932a.

40) - Further observations on the parafollicular cells of the mammalian thyroid. Anat. Rec. $53: 339-347,1932 \mathrm{~b}$.

41) : The 'parenchymatous' cell of BABER, 'protoplasma-reichen Zellen' of HÜRTHLE, and the 'parafollicular' cells of mammalian thyroid. Anat. Rec. 56 : 131-141, 1933.

42) Oguri, M.: Seasonal histologic changes in the ultimobranchial gland of goldfish. Bull. jap. Soc. Scientific. Fisheries. 39(8) : 851-853, 1973.

43) Pang, P.K.T.: Calcitonin and ultimobranchial gland in fishes. J. Exp. Zool. 178 : 89-100, 1971.

44) Pearse, A.G.E.: The cytochemistry of the thyroid $\mathrm{C}$ cells and their relationship to calcitonin. Proc. Roy. Soc. $164: 478-487,1966$.

45) and Carvalheira, A.F.: Cytochemical evidence for an ultimobranchial origin of rodent thyroid C cells. Nature. 241: 929-930, 1967.

46) Rable, H.: Die Entwicklung der Derivate des Kiemendarmes beim Meerschweinchen. Arch. mikr. Anat. 82: 79-147, 1913.

47) Rasquin, P., and Rosenbloom, L. : Endocrine imbalance and tissue hyperplasia in teleosts maintained in darkness. Bull. Amer. Mus. Nat. Hist. $104: 359-426,1954$.

48) Robertson, D.R.: The ultimobranchial body in Rana pipiens. II. The various cell types and the fate of secretory granules in the parenchyma of the young adult. Z. Zellforsch. mikrosc. Anat. 67: 584-599, 1965.

49) - : The ultimobranchial body in Rana pipiens. V. The cell cycle studied with tritiated thymidine. Trans. Amer. microsc. Soc. $86: 195-203,1967$.

50) - Some morphological observation of the ultimobranchial gland in the rainbow trout, Salmo gairdneri. J. Anat. 105 : 115-127, 1969.

51) - and Bell, A.L.: The ultimobranchial body in Rana pipiens. I. The fine structure. Z. Zellforsch. mikrosk. Anat. $66:$ 118-129, 1965.

52) Rogers, W.M.: The fate of the ultimobranchial body in the white rat (Mus Norvegius albinous). Amer. J. Anat. 38 : 349-377, 1927.

53) Sato, Tai.: A modified method for lead staining of thin sections. J. Electron. Microscopy. 17(2): 158-159, 1968.

54) - and Shamoto, M.: A simple rapid polychrome stain for epoxy-embedded tissue. Stain. Technol. $48: 223-227,1973$.

55) Sato, Tam.: The postnatal histogenesis of the thyroid gland of the golden hamster (Cricetus auratus). Okajimas Fol. anat. jap. 33:225-253, 1959.

56) - Ishikawa, K., Aoi, T., Kitoh, J., and Sugiyama, S.: Electron microscopic observations on the development of the parafollicular cells from the ultimobranchial cyst in the thyroid gland of the mouse. Okajimas Fol. anat. jap. 42:91-105, 1966.

57) Saxén, L., and Toivonen, S.: The development of the ultimobranchial body in Xenopus laevis Daudin and its relation to the thyroid gland and epithelial bodies. J. Embryol. exp. Morphol. 3 : 376-384, 1955.

58) Schaefer, K.: Morphologische und physiologische Untersuchungen am ultimobranchialen Körper von Triturus vulgaris und T. alpestris. Z. wiss. Zool. 151: 22-38, 1938.

59) Sehe, C. T.: Radioautographic studies on the ultimobranchial body and thyroid gland in vertebrates; Fishes and amphibians. Endocrinology. 67:674-684, 1960.

60) : Comparative studies on the ultimobranchial body in reptiles and birds. Gen. Comp. Endocrinology. 5: 45-59, 1965.

61) Shamoto, M., and Sato, T.: A simple technic for light and electron microscopic observation of the same sections. Amer. J. Clini. Pathology. 62 (6); 783-790, 
1974.

62) Steinitz, H., and Stone, L.S.: Observations on the ultimobranchial body of adult newt, Triturus. v. viridescens. Anat. Rec. $120: 435-447,1954$.

63) Stoeckel, M.E., and Porte, A.: Sur l'ultrastructure des corps ultimobranchiaux du Poussin. C. r. hebd. Séanc. Acad. Sci, Paris, Sér. D265 2051-2053, 1967a.

64) - - and Canguilhem, B.: Sur l'ultrastructure des cellules parafolliculaires de la thyroide du hamster sauvage (Cricetus cricetus). C. r. hebd. Séanc. Acad. Sci., Paris, Sér. D264 : 2490-2492, $1967 \mathrm{~b}$.

65) — : Étude ultrastructurale des corps ultimobranchiaux du poulet. I. Aspect normal et developpment embryonnaire. Z. Zellforsch. $94: 495-512,1969$.

66) Sugiyama, S.: The fate of the ultimobranchial body of the albino rat with special reference to the formation of the thyroid gland. Okajimas Fol. anat. jap. 19: 333-341, 1940.

67) - The development and the fate of the ultimobranchial body in the mouse with special emphasis on its relation to the thyroid gland. Jap. J. med. Sci., ptl. Anat. 9 : 153-168, 1942.

68) - : Studies of the postnatal histogenesis of the thyroid gland of the guinea pig. I. The thyroid cells (follicle cells and parafollicular cells). Anat. Rec. 120 : 368-378, 1954.

69) - Embryonic development of human thyroid gland and ultimobranchial body. Acta. endocr. (Kbh). Suppl. 138, 7th Acta Endocr. Congr. Stockholm, p. 179, 1969.

70) - The emoryology of the human thyroid gland including ultimobranchial body and others related. Ergeb. Anat. Entwickl-Gesch. Bd. 44H. 2: 1-112, 1971.

71) - Kitoh, J., and Yokota, S.: On the problem of the development of the parafollicular cells from the human ultimobranchial body in prenatal life. Okajimas Fol. anat. jap. $46: 59-63,1969$.

72) Swaftz, G.E., and Hertzel, N.E.: The development of the ultimobranchial bodies and their relationship to thyroid formation in the golden hamster. Trans. Amer. Microsc. Soc. 83 : 384-391, 1964.

73) Takagi, I., Yamada, K., and Sugiyama, S.: The embryonic and postembryonic development of the ultimobranchial body of the hamster (Cricetus auratus)-in relation to the differentiation of the parafollicular cells. Okajimas Fol. anat. jap. $50(6): 359-376,1974$.

74) Tashiro, M.: Electron microscopic observation of the cyst of ultimobranchial origin found in the thyroid gland of a dog. Nagoya. J. Med. Sci. 24 : 159-163, 1963.

75) - Electron microscopic studies of the parafollicular cells in the thyroid gland of the dog. Okajimas Fol. anat. jap. 39 : 191-211, 1964.

76) Tauber, S. D.: The ultimobranchial origin of thyrocalcitonin. Proc. Nat. Acad. Sci. 58 : 1684-1687, 1967.

77) Togari, C., and Sugiyama, S.: The development and fate of the ultimobranchial body of the rabbit with special reference to the formation of the thyroid gland. Okajimas Fol. anat. jap. 23 : 305-322, 1951.

78) Van Bemmeln, J.F.: Über vermutliche rudimentäre Kiemenspalten bei Elasmobranchiern. Mitteil. Zool. Stat. Neapel. $6: 165-184,1886$ a.

79) — : Über die Supraperikardialkörper. Anat. Anz. $4: 400-407,1886 \mathrm{~b}$.

80) Watson, M.L.: Staining of tissue sections for electron microscopy with heavy metals. II. Application of solutions containing lead and barium. J. Biophys. and Biochem. Cytol. 4 : 727-730, 1958.

81) Watzka, M.: Vergleichende Untersuchungen über den ultimobranchialen Körper. Z. mikrosk.-anat. Forsvh. 34 : 485-533, 1933. 


\section{Key to Abbreviations used in Figures}

BV : Blood vessel

CT: Connective tissue

D : Desmosome

DC: Dark cell

DO : Dense osmiophilic cytoplasmic granule

ER : Rough-surfaced endoplasmic reticulum

FB : Filament bundle

G: Golgi zone

GC: Granule-rich cell
ID : Interditation

LC : Light cell

$\mathrm{M}$ : Mitochondria

$\mathrm{N}$ : Nucleus

$\mathrm{Nu}$ : Nucleolus

SC: Semi-dark cell

SG: Secretory granule

$\mathrm{U}$ : Ultimobranchial body

UF : Ultimobranchial follicle

The scale indicates $1 \mu \mathrm{m}$. 


\section{Explanation of Figures}

\section{Plate I}

Fig. 1. Ultimobranchial body of crucian carp. Follicular and cord-like arrangements of the ultimobranchial cells. Blood vessels are scattered in connective tissues. Thick section stained with Sato's method. $\times 750$

Fig.s 2, 3. Follicular walls of the ultimobranchial body in crucian carp showing the light and dark cells. Fig. 2. $\times 2,500$, Fig. $3 . \times 2,000$.

Fig. 4. Follicular walls of the ultimobranchial body in crucian carp showing the light, dark and semi-dark cells. $\times 5,500$ 

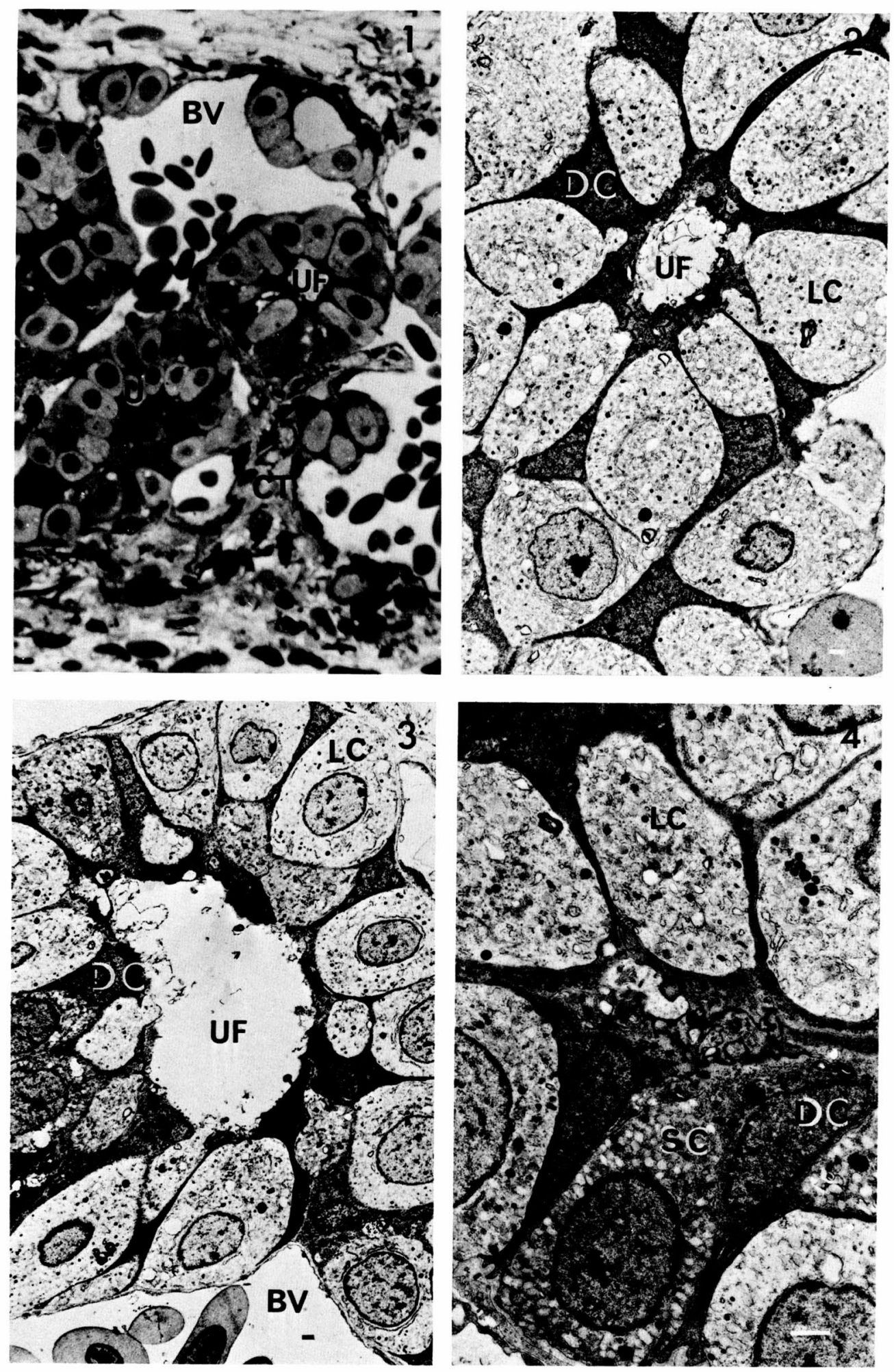


\section{Plate II}

Fig. 5. Part of the light cell in crucian carp. Golgi zone, rough-surfaced endoplasmic reticulum, secretory granules and tangled filament bundles are seen. $\times 8,200$

Fig. 6. Apical part of the dark cell in crucian carp. Well developed interdigitations are seen between dark cells. Golgi zone, mitochondria, desmosomes and secretory granules are seen. $\times 9,500$ 

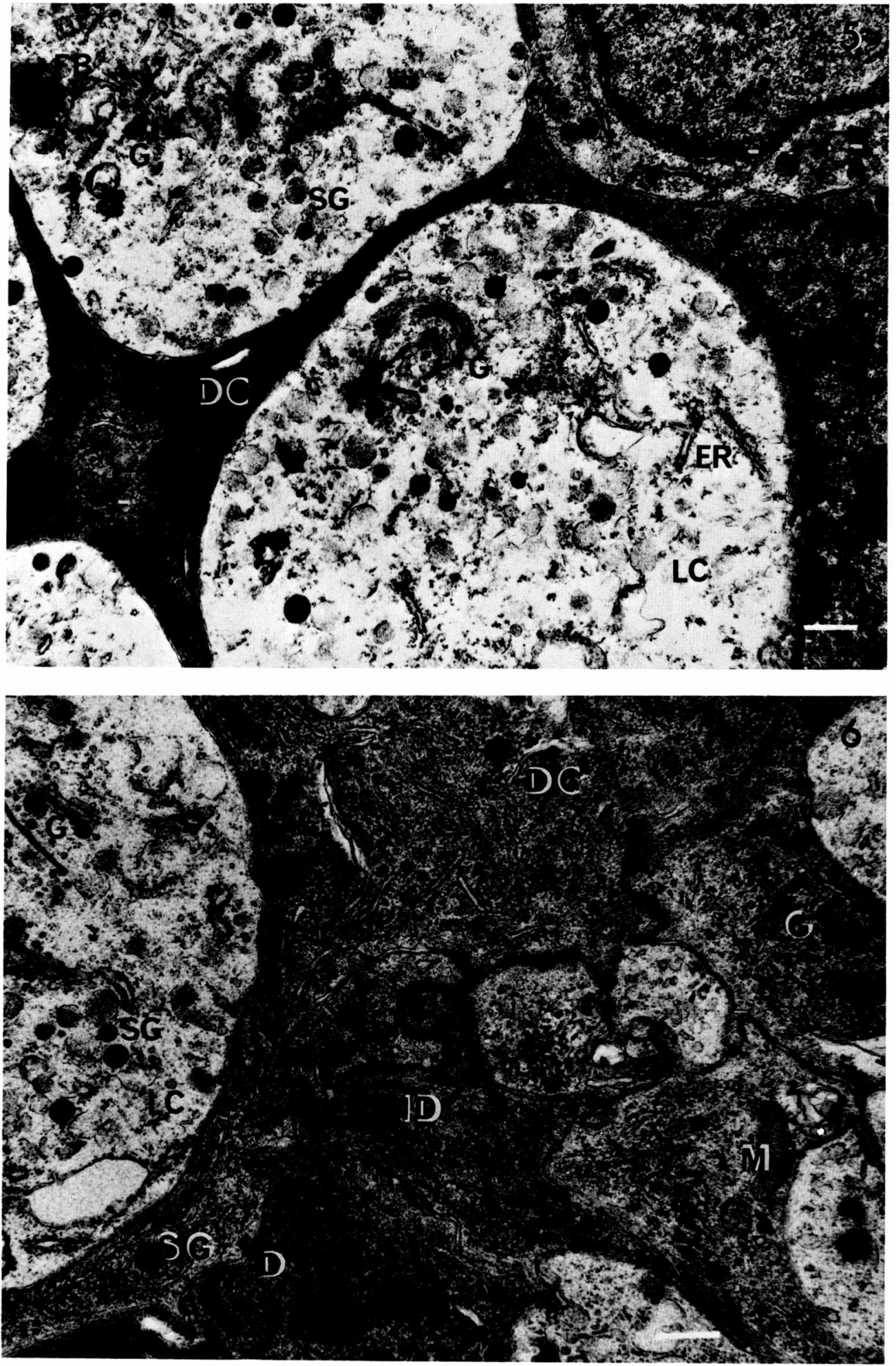


\section{Plate III}

Figs. 7-14. Lumenal surface of the ultimobranchial follicle in crucian carp. There appears to be a discharge of granules, cytoplasmic, material and cellular debris into the lumen. Fig. 7. $\times 5,000$, Fig. $8 . \times 3,000$, Fig. 9. $\times 4,000$, Fig. 10. $\times 45,000$, Fig. 11. $\times 3,200$, Fig. 12. $\times 45,000$, Fig. $13 . \times 42,000$, Fig. 14 . $\times 42,000$. 

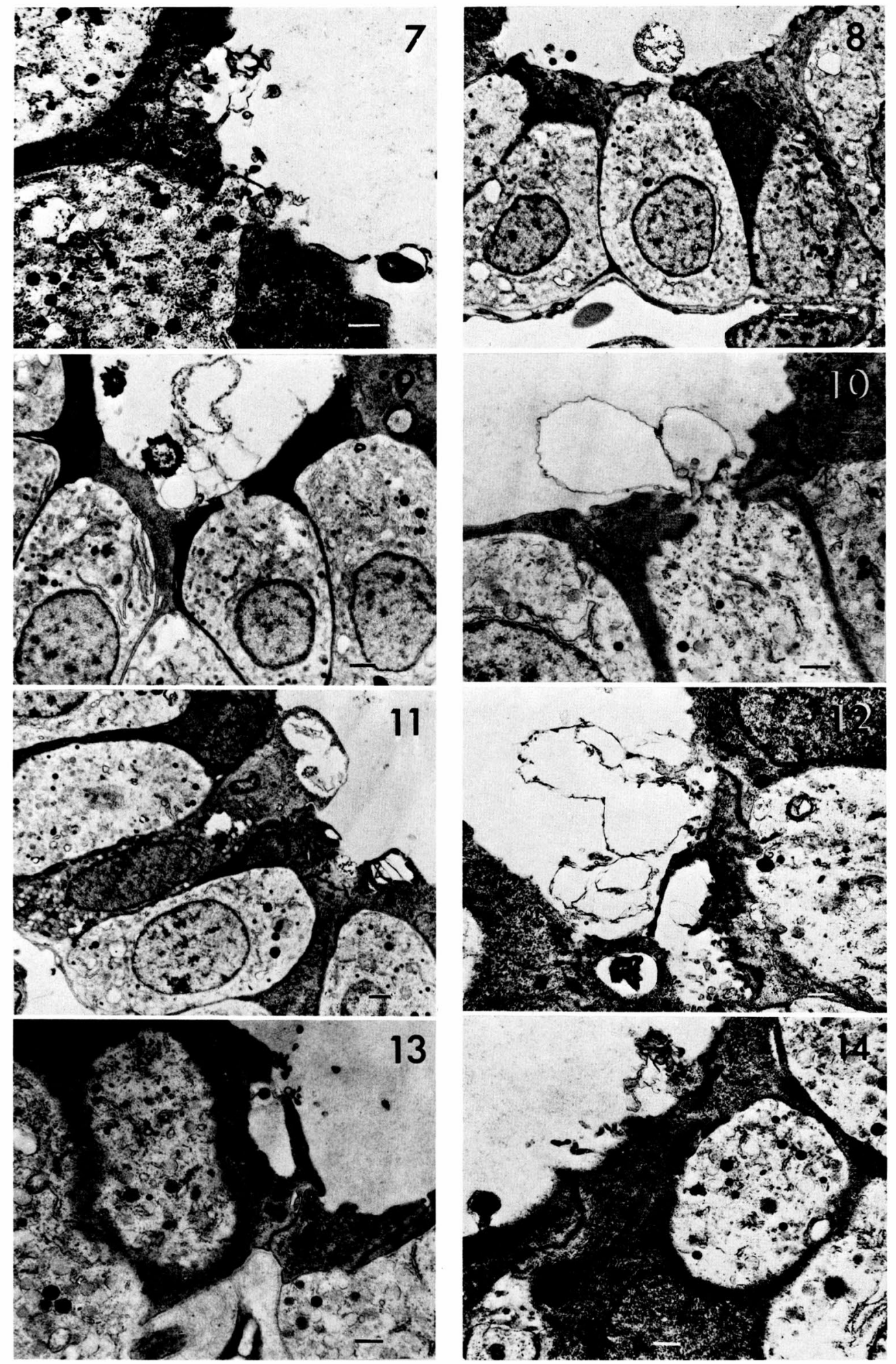


\section{Plate IV}

Fig. 15. Granule-rich cell of the ultimobranchial body in crucian carp. Granule-rich cell has accumulated granules within the cytoplasm. $\times 4,600$

Fig. 16. High magnification of the granule-rich cell in Figure 15. View of many secretory membrane-bounded granules. Dense nucleolus is seen in the nucleus. $\times 14,000$ 

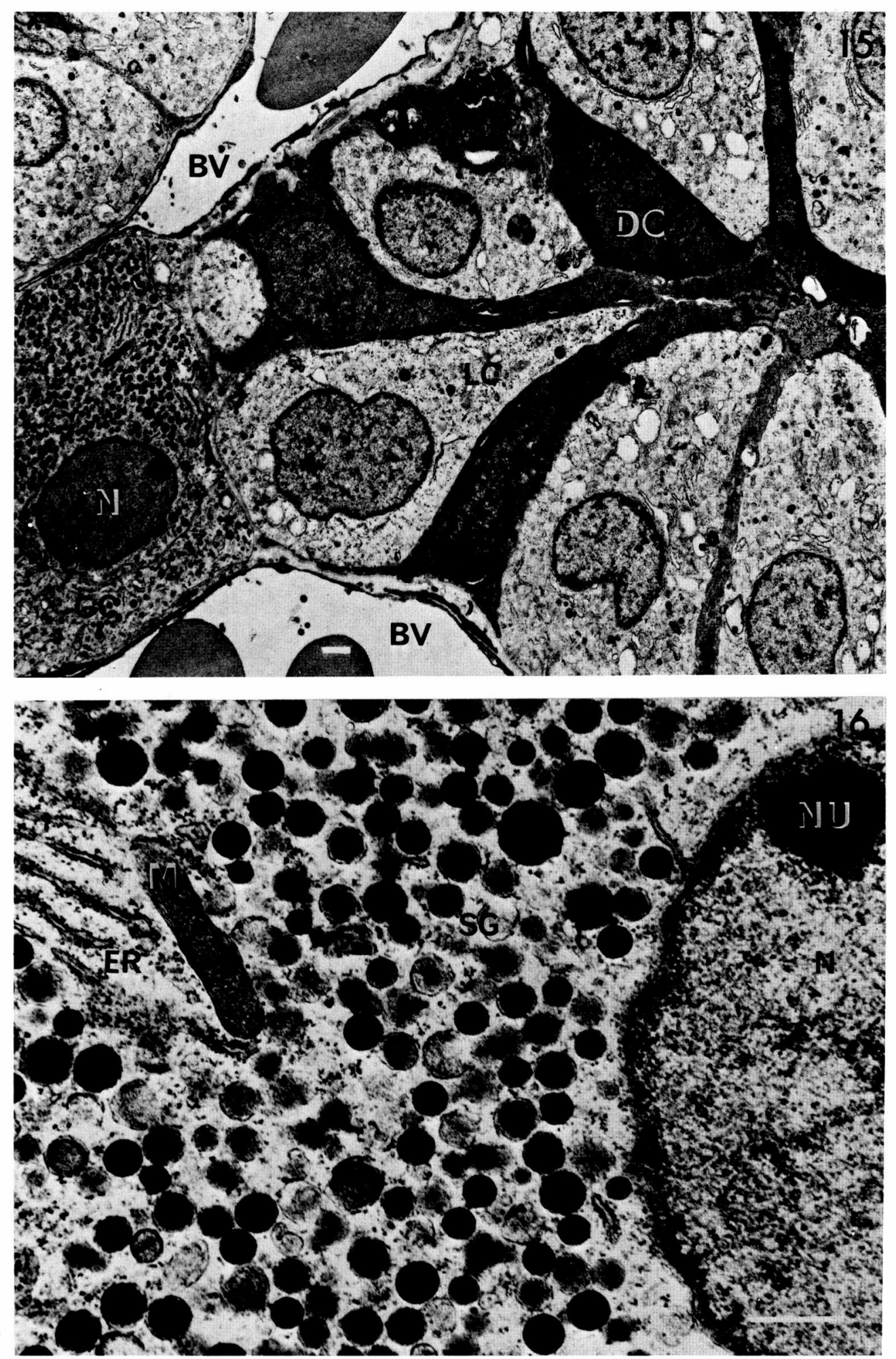


\section{Plate V}

Figs. 17, 18. See the front page Figure 15. Fig. 17. $\times 8,800$, Fig. 18. $\times 9,000$

Fig. 19. Dense osmiophilic inclusion composed of radiating fibres enclosed within an apical vesicle. $\times 5,000$ 

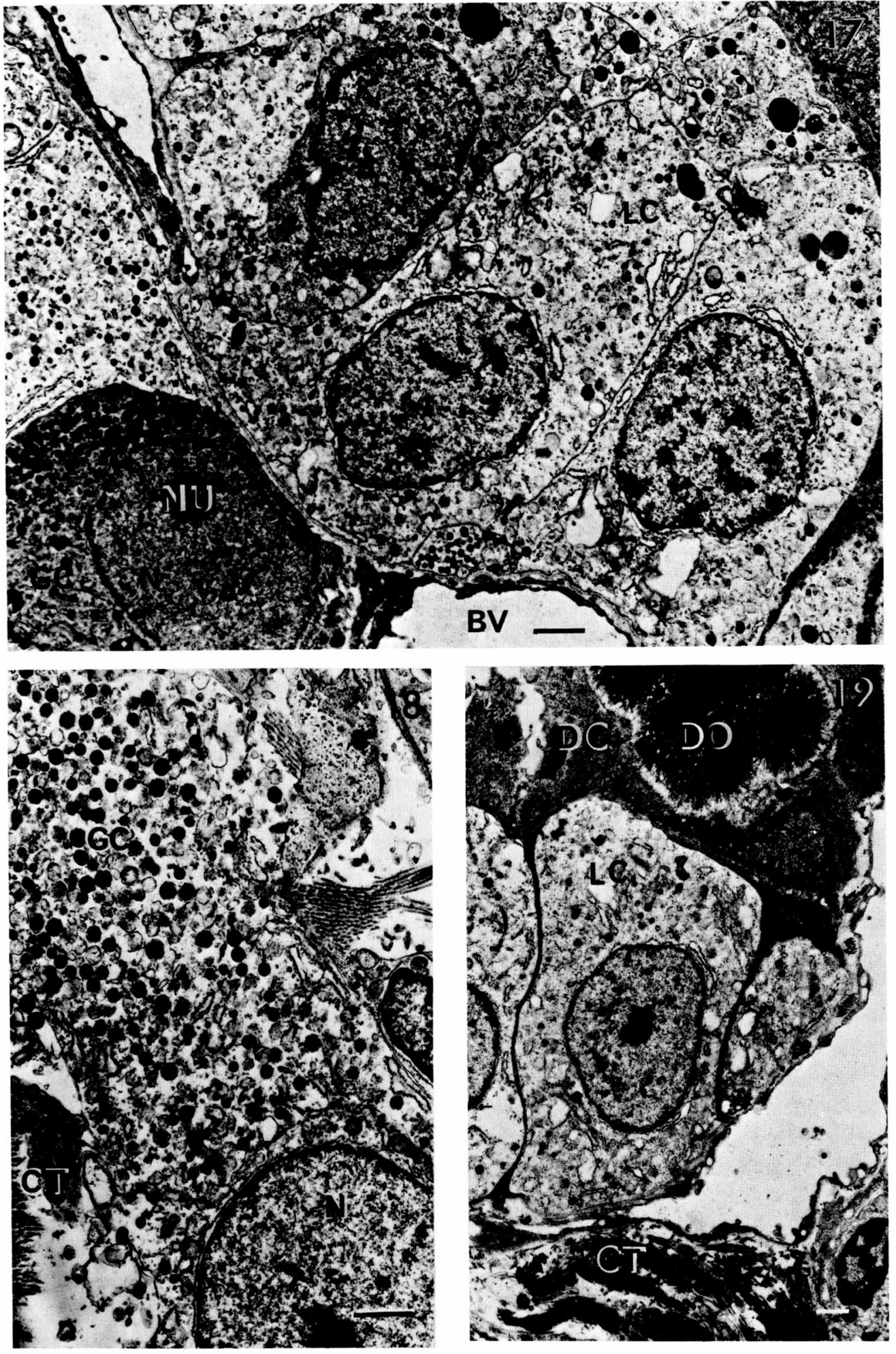